\title{
Plethoric Face
}

National Cancer Institute

\section{Source}

National Cancer Institute. Plethoric Face. NCI Thesaurus. Code C99018.

A finding that refers to a person with erythematous face. 